\title{
What do unit root tests tell us about unemployment hysteresis in transition economies?
}

\author{
Ebru Çağlayan Akay \\ Department of Econometrics, Marmara University, Istanbul, Turkey \\ Zamira Oskonbaeva \\ Department of Economics, Kyrgyz-Turkish Manas University, Bishkek, \\ Kyrgyzstan, and \\ Hoşeng Bülbül \\ Department of Econometrics, Marmara University, Istanbul, Turkey
}

\begin{abstract}
Purpose - This study aims to examine the hysteresis hypothesis in unemployment using monthly data from 13 countries in transition.

Design/methodology/approach - Stationarity in the unemployment rate of selected transition economies was analyzed using four different group unit root tests, namely, linear, structural breaks, nonlinear and structural breaks and non-linear.

Findings - The empirical results show that the unemployment hysteresis hypothesis is valid for the majority of transition economies, including Bulgaria, Croatia, the Czech Republic, Estonia, Hungary, the Kyrgyz Republic, Latvia, Lithuania, Poland, Romania and Slovenia. However, the results strongly reject the null hypothesis of unemployment hysteresis for the Kazakhstan and the Slovak Republics.

Originality/value - This study revealed that, for countries in transition, advanced unit root tests exhibit greater validity when compared to standard tests
\end{abstract}

Keywords Unemployment hysteresis, Transition economies, Fourier unit root test,

Non-linear unit root test

Paper type Research paper

\section{Introduction}

The theory of hysteresis, developed by Blanchard and Summers $(1986,1987)$, indicates that cyclical variations or shock effects will persist because of the rigidity of the labor market. Hysteresis can include the delayed effects of unemployment, whereby the unemployment rate continues to rise even after the economy has recovered. It can indicate a permanent

(C) Ebru Çağlayan Akay, Zamira Oskonbaeva and Hoseng Bülbül. Published in Applied Economic Analysis. Published by Emerald Publishing Limited. This article is published under the Creative Commons Attribution (CC BY 4.0) licence. Anyone may reproduce, distribute, translate and create derivative works of this article (for both commercial and non-commercial purposes), subject to full attribution to the original publication and authors. The full terms of this licence maybe seen at http:// creativecommons.org/licences/by/4.0/legalcode

Disclosure statement: No potential conflicts of interest were reported by the authors.

The authors thank the editor and two anonymous reviewers whose comments/suggestions helped to improve and clarify this manuscript.

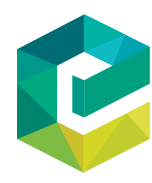

Applied Economic Analysis Vol. 28 No. 84,2020 pp. $221-238$ 
AEA 28,84 change in the workforce from the loss of job skills making workers less employable even after a recession has ended. Hysteresis occurs when current unemployment is dependent on past values, with the sum of their coefficients equal to or very similar to unity. In other words, the authors developed a new unemployment theory that assumes the unit root process of unemployment dynamics. The theory states that unemployment shocks have lasting long-term effects on the variable, which will be well-defined as unit root process. Accordingly, after a shock, the unemployment rate will not return to its equilibrium in the long term (Bolat et al., 2014). According to Carlin and Soskice (1990), unemployment hysteresis implies that the equilibrium rate of unemployment is path-dependent. Smyth (2003) asserted that, under the unemployment hysteresis theory, cyclical changes in the economy may have a lasting impact on the rates of unemployment. The validity of this hypothesis is of great importance as it impacts on policy. If unemployment is defined as a unit root process, policymakers should focus on structural reforms to mitigate adverse shocks. On the contrary, if unemployment is stationary, the goal would be to avoid shortterm imbalances. As unemployment hysteresis is associated with non-stationary unemployment rates, unit root tests have been widely used since the 1980s to investigate the validity of the hysteresis effect. The results obtained are, however, highly dependent on the statistical power of the unit root tests applied. If the presence of dynamics is misspecified in standard unit root tests, all tests have lower power (Enders and Granger, 1998).

Since the seminal work of Blanchard and Summers (1986), researchers have conducted substantial empirical analyzes to evaluate the validity of the hysteresis hypothesis. The extant research has not expounded on transition economies, hence, these studies are scarce. Transition economies can be an interesting case to explore the unemployment hysteresis hypothesis because of their extensive time under one regime. These economies have also started to realize social and economic reforms to keep pace with the ever-changing international environment. Transition economies underwent a deep transformation in the social, economic and political sphere. Integration into global value chains was accompanied by high levels of unemployment, often reaching double digits (Terrell and Jurajda, 2007). Changing global human values has encouraged countries to participate in these new conditions and develop new relations between employers and employees; the labor market of former command economies underwent deep transformation. These structural changes in the labor market have motivated our study.

This study contributes to the existing literature because these transition economies are characterized by profoundly changing labor markets, warranting a thorough understanding of the hysteresis effect. It examines the validity of unemployment hysteresis for selected transition economies, namely, Bulgaria, Croatia, the Czech Republic (CzechR), Estonia, Hungary, the Kyrgyz Republic (KyrgyzR), Latvia, Lithuania, Poland, Romania, Slovenia, Kazakhstan and the Slovak Republic (SlovakR). We use various unit root tests that consider linear, non-linear structures and structural breaks to determine whether the initial specifications of the series affect the performance of unit root test results on unemployment hysteresis. The reason why these tests are used is when the transition between the regimes is a smooth one and/or there exist multiple structural breaks in time series, the advanced unit root tests provide greater power when compared with standard tests. The results of these tests support that the hysteresis hypothesis is accepted for all transition economies except Kazakhstan and SlovakR.

The study is organized as follows: Section 2 addresses unemployment in transition economies. Sections 3 and 4 present the literature and data used, respectively. In Section 5 , the methodology and empirical findings are presented. Finally, Section 6 concludes the study. 


\section{Unemployment in transition economies}

During the past decades of the 20th century, transition economies underwent profound changes throughout their economies. The transition process inevitably led to crises (Nesporova, 2002). The severity and scale of this crisis depended on many factors and had a significant impact on the economic and social development of countries in Central and Eastern Europe (CEE) and the Commonwealth of Independent States (CIS).

Transition economies witnessed major layoffs during the 1990s, primarily influenced by the inability of socialist companies to restructure and offer competitive products (Petreski, 2020). The first phase of the transition from a centrally planned to market economy resulted in a recession and a major reallocation of labor and capital; thus, it is expected that, in most post-communist economies, unemployment rates grew rapidly from their theoretically zero base to double digits (Terrell and Jurajda, 2007). Transition economies vary significantly in their economic performance, as observed in the labor market, presenting an unemployment challenge. Many countries have managed to tackle unemployment, while others continue to face severe repercussions.

In some transformation economies, unemployment can be attributed to slow economic recovery. Conversely, there is evidence that in those economies where economic growth has been achieved, unemployment continues to be a challenge. With the dissolution of the Soviet Union, open unemployment began to accelerate. Scholars and policymakers asserted that it was important to tackle economic issues first so that when the economy started to recover, which they expected to be imminent, it would automatically improve labor market outcomes. However, these expectations were unrealized (Nesporova, 1999).

Generally, the initial transformation shock resulted in decreasing employment rates, increasing unemployment, decreasing working hours and declining real wages. However, countries were affected differently by these adjustment mechanisms (Svejnar, 1999). For instance, CEE countries exhibited declining employment rates and increasing unemployment, followed by a slight decline in real wages. In contrast, the former Soviet Union experienced a considerable drop in real wages, while unemployment increased slightly with limited employment rate decreases (Boeri and Terrell, 2002). The 2008 global financial crisis also worsened labor market outcomes.

Scholars argued that persistent high unemployment in transition economies could be attributed to macroeconomic and structural reforms (Nesporova, 2002) or tight labor market regulations. Boeri and Terrell (2002) asserted that it is difficult to associate this persistent unemployment with labor market flexibility, but rather attributed it to ineffectively and inconsistently implemented unions, minimum wages and employment protection legislation. Hungary, for instance, has the most flexible employment protection legislation, while the Russian Federation and Slovenia are most restrictive (Cazes, 2002). Vocational training was given significant attention in Hungary, Croatia and CzechR, while in other countries the implementation of labor market training has been ineffective (Nesporova, 1999).

\section{Literature}

Hysteresis theory has drawn considerable interest from researchers from various countries since the seminal work of Blanchard and Summers (1986). The extant research indicates contradictory findings when applying various unit root and stationary tests for time series or panel data. These studies are summarized in Table 1.

As can be seen from Table 1, earlier studies used conventional unit root tests. As hysteresis is associated with non-stationary levels of unemployment, unit root tests have 


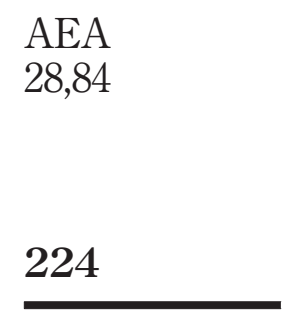

$\mid$

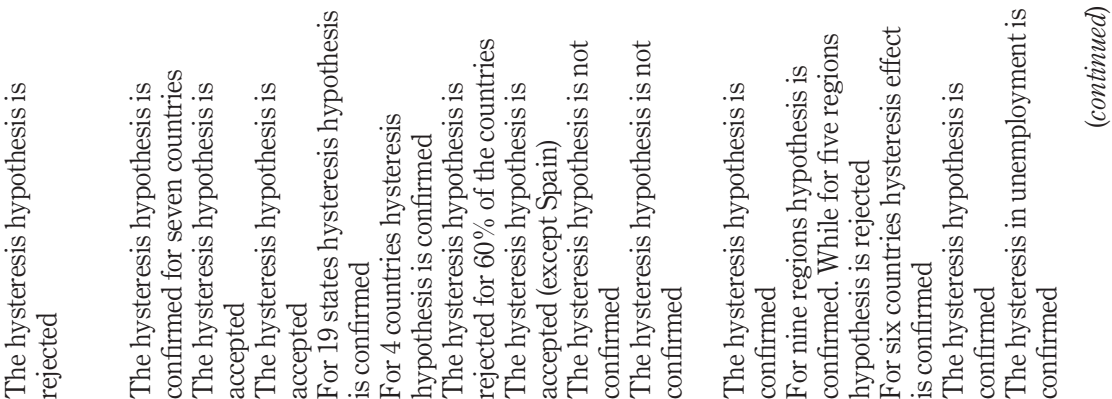

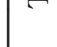

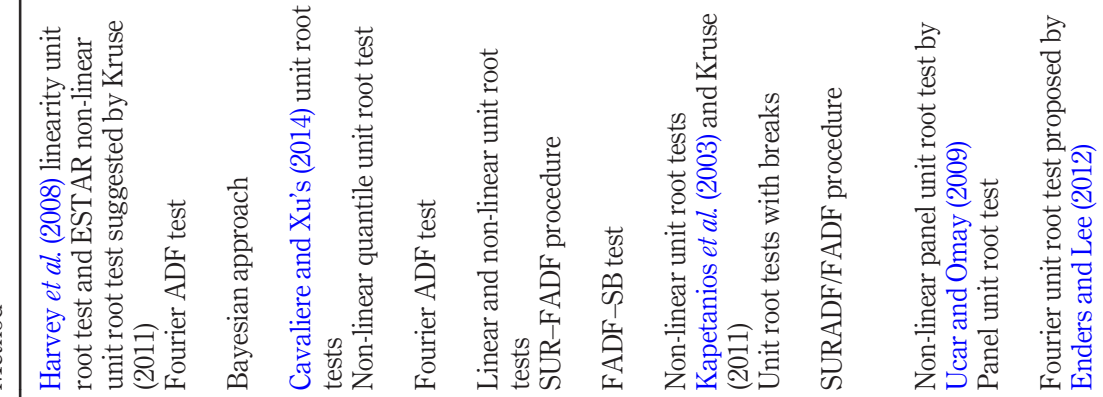

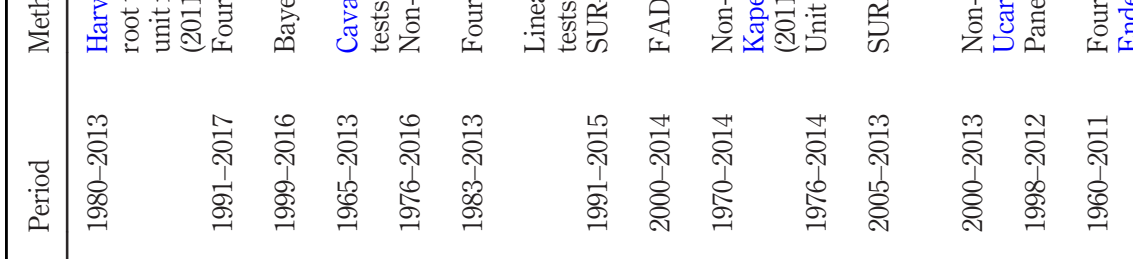

Table 1.

Summary of contradictions in extant hysteresis research

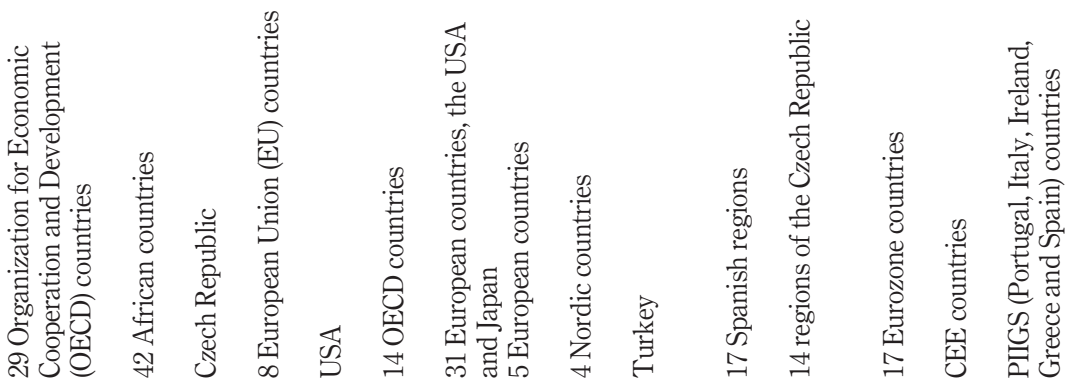

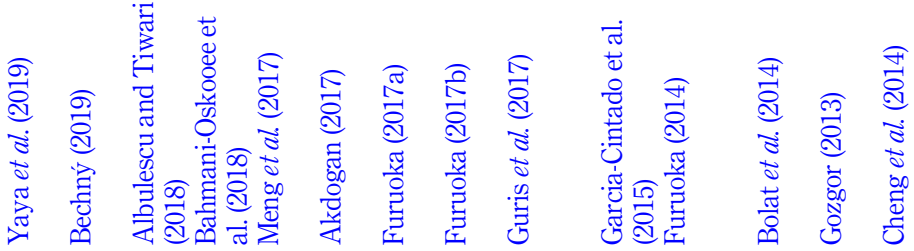




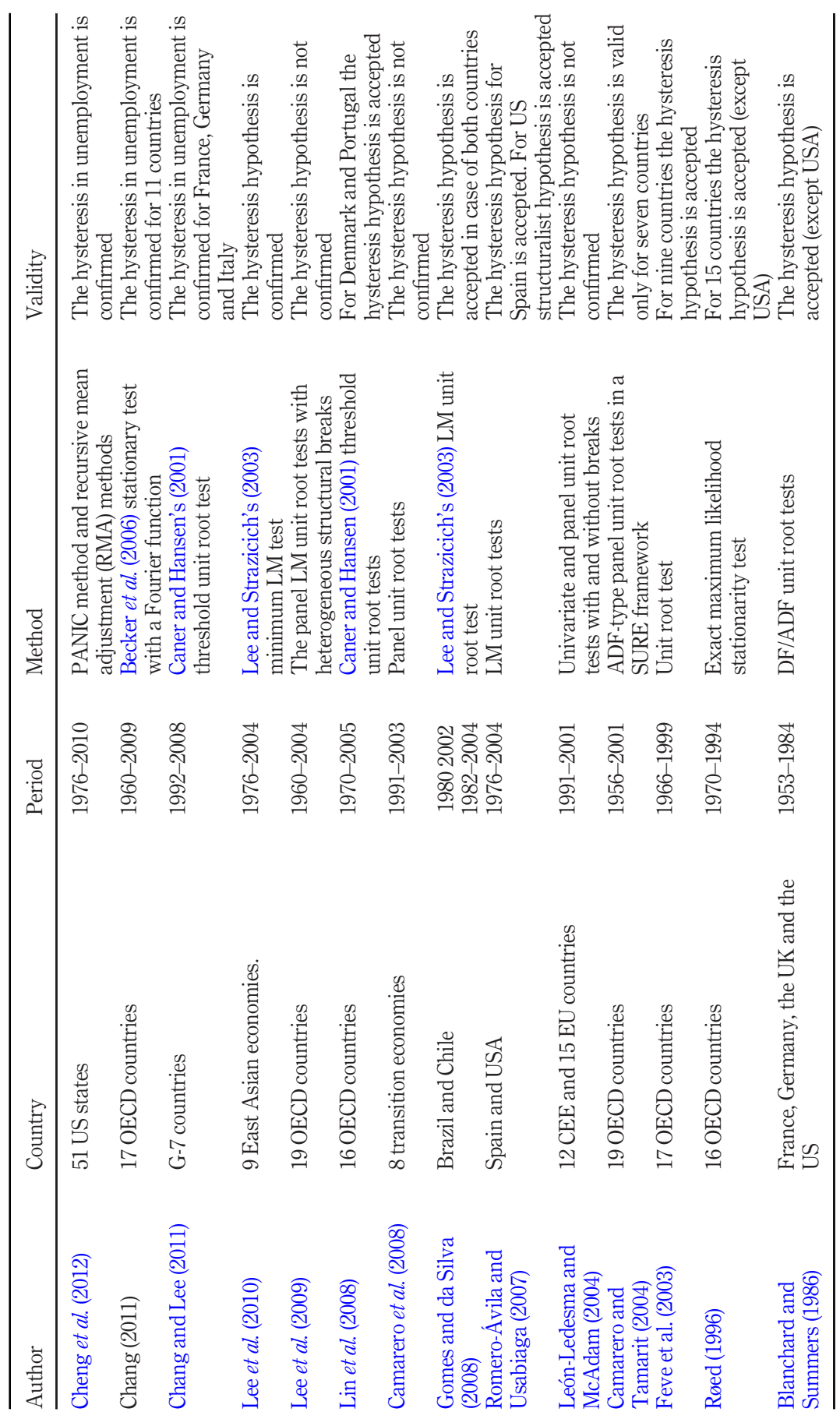

Transition

economies

225

Table 1. 
AEA 28,84 been used to assess its validity (Arestis and Mariscal, 2000; Blanchard and Summers, 1986; Brunello, 1990; Røed, 1996).

It is evident from Table 1 that the number of studies dealing with the hysteresis issue in transition economies is scarce. Unemployment hysteresis in CEE countries was examined by León-Ledesma and McAdam (2004), Camarero et al. (2005) and Gozgor (2013), however, as far as we are aware, CIS countries have yet to be investigated.

\section{Data}

In this study, we used the monthly unemployment rates for the selected 13 transition economies from 2000:01 to 2017:04, except for Estonia and Kazakhstan whose data start dates were 2000:02 and 2001:01, respectively. The countries analyzed are Bulgaria, Croatia, CzechR, Estonia, Hungary, Kazakhstan, KyrgyzR, Latvia, Lithuania, Poland, Romania, SlovakR and Slovenia. Data were obtained from the International Monetary Fund database (International Financial Statistics, 2019).

The unemployment time series is generally influenced by seasonality. In the literature, it is very common for researchers to apply a seasonal adjustment to remove the influence of fluctuations in the level of the series and to observe the cyclical, underlying trend and other non-seasonal movements in the series (Akdogan, 2017; Cheng et al., 2012; Garcia-Cintado et al., 2015; Gustavsson and Österholm, 2006; Romero-Ávila and Usabiaga, 2007,etc.). In our empirical analysis, we use seasonally adjusted monthly data on unemployment rates for the 13 countries in transition.

\section{Methodology and empirical findings}

This study examines whether the hysteresis effect is valid for transition economies by considering different unit root tests. First, we used different linearity tests to detect the existence of non-linearities of the unemployment series for all selected transition economies. This is important because a failure to recognize the non-linearity of a time series can often lead to poor parameter estimates (Bisaglia and Gerolimetto, 2014). We applied different wellknown linearity tests, named after McLeod and Li (1983), Keenan (1985), Tsay (1986), Harvey and Leybourne (2007) and Harvey et al. (2008). The results of these tests are listed in Table 2.

According to the results given above regarding the McLeod and Li (1983) linearity test, the unemployment series of all countries display non-linear characteristics. However, the other linearity test results are contradictory. This can be attributed to the differences in the mechanism of the tests. Because of the contradictory results, we investigate unemployment hysteresis in the transition economies by considering both linear and non-linear unit root tests in the study.

The performance of unit root tests depends on the specification of the series, which includes deterministic, trend, non-linear and structural breaks. By making stronger and more precise predictions, it is possible to accurately reveal the structure of the data. Alternatively, incomplete and/or misidentification of the data leads to insufficient and less sensitive predictions. Because of the contradictory results of the linearity tests, we consider four groups of unit root tests:

(1) Linear unit root tests: Dickey-Fuller/Augmented Dickey-Fuller (Dickey-Fuller, 1979), Phillips-Perron (Phillips and Perron, 1988), Kwiatkowski et al. (KPSS, 1992), Elliott et al. (Elliott et al., 1996).

(2) Structural breaks unit root tests: Zivot-Andrews (ZA, 1992) and Fourier KPSS (Becker et al., 2006). 


\begin{tabular}{|c|c|c|c|c|c|c|c|c|c|}
\hline \multirow[b]{2}{*}{ Tests } & \multicolumn{8}{|c|}{ 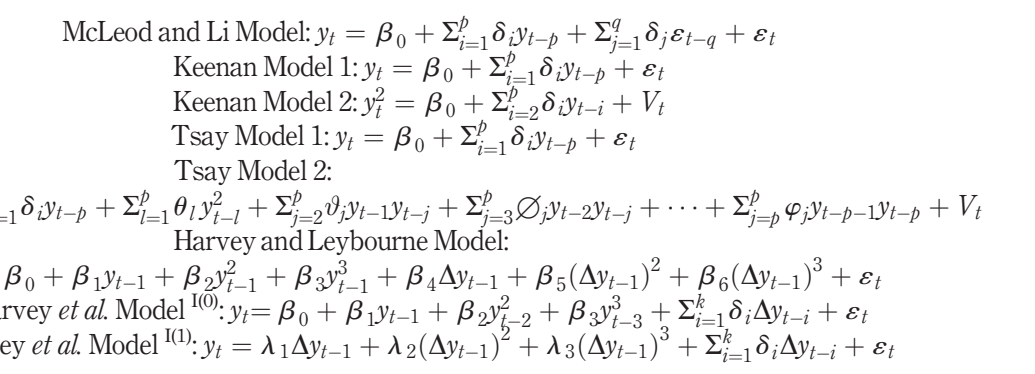 } & $\begin{array}{r}\text { Transition } \\
\text { economies } \\
\\
227\end{array}$ \\
\hline & McLeod and Li & $\mathrm{k}$ & Keenan & Tsay & Harvey & and Leybc & urne & Harvey et al. & \\
\hline Bulgaria & $(0.00)^{* * *}$ & 3 & 0.467 & 0.713 & 9.87 & $9.75^{* *}$ & 9.68 & $5.41^{*}$ & \\
\hline oatia & $(0.00)^{* * * *}$ & 6 & 2.409 & $2.018^{* * *}$ & $15.98^{* * *}$ & 15.79 & 15.68 & $13.44^{* * *}$ & \\
\hline echR & $(0.00)^{* * * *}$ & 4 & 0.026 & $1.676^{*}$ & 1.32 & 1.28 & 1. & 0.26 & \\
\hline tonia & $(0.00)^{* * *}$ & 10 & $8.537^{* * * *}$ & $1.619^{* *}$ & 7.48 & 7.42 & 7.38 & 3.30 & \\
\hline ingary & $(0.00)^{* * * *}$ & 3 & 0.036 & 0.532 & 2.33 & 2.30 & 2.28 & 0.73 & \\
\hline zakhstan & $(0.00)^{* * * *}$ & 3 & 1.478 & $7.186^{* * *}$ & $49.52^{* * *}$ & 49.00 & 48.71 & $58.96^{* * *}$ & \\
\hline yrgyzR & $(0.00)^{* * *}$ & 1 & 0.402 & 0.132 & 10.43 & $10.25^{* *}$ & 10.15 & 0.58 & \\
\hline Latvia & $(0.00)^{* * * *}$ & 9 & $9.594^{* * * *}$ & 0.874 & 7.35 & 7.29 & 7.25 & 3.74 & \\
\hline huania & $(0.00)^{* * * *}$ & 7 & $5.275^{* *}$ & $1.686^{* *}$ & 7.72 & 7.64 & 7.5 & 3.90 & \\
\hline land & $(0.00)^{* * * *}$ & 2 & 0.003 & 0.967 & 3.44 & 3.31 & 3.23 & 3.29 & \\
\hline mania & $(0.00)^{* * * *}$ & 2 & 0.047 & 1.929 & 5.71 & 5.48 & 5.35 & $4.80^{*}$ & \\
\hline $\mathrm{akR}$ & $(0.00)^{* * *}$ & 2 & 0.145 & $4.712^{* * *}$ & 5.36 & 5.13 & 5.0 & 2.92 & \\
\hline Slovenia & $(0.00)^{* * * *}$ & 7 & 1.745 & 1.107 & 2.40 & 2.37 & 2.35 & 0.43 & \\
\hline \multicolumn{10}{|c|}{$\begin{array}{l}\text { Notes: McLeod and Li (1983) test statistics are obtained using the squares of residuals obtained from the } \\
\text { ARMA model in the Ljung and Box (1978) statistic; in the Tsay (1986) test, residuals obtained from Models } \\
1 \text { and } 2 \text { equations are regressed and } F \text { test statistics are obtained from this equation; in the Keenan (1985) } \\
\text { test, residuals obtained from Models } 1 \text { and } 2 \text { equations are regressed and } F \text { test statistics are obtained from } \\
\text { two equations; } \chi_{4}^{2} \text { Table critical values of and the } \chi_{2}^{2} \text { table critical values of Harvey et al. (2008) test are } 9.21 \text {, } \\
5.99,4.60 \text {, respectively; ***, ** and *simply rejection of the linearity at the } 1 \%, 5 \% \text { and } 10 \% \text { levels, } \\
\text { respectively; values in parentheses indicate prob. values }\end{array}$} \\
\hline
\end{tabular}

(3) Non-linear unit root tests: Kapetanios et al. (KSS, 2003), Sollis (2009), Cuestas and Garratt (CG, 2011) and Kruse (2011).

(4) Structural breaks and non-linear unit root tests: Guris (FKruse, 2019).

These different tests show how the initial specifications of the series affect the performance of unit root results.

\subsection{First group: linear unit root tests}

The first approach used to determine the stationary properties of the series is Dickey and Fuller (1979), which is one of the linear unit root tests. In the following studies, there have been important developments in the unit root testing process. Following this test, many other tests, such as Phillips and Perron (1988), Kwiatkowski et al. (1992) and Elliott et al. (1996) constitute the basis of unit root literature. Since linear unit root tests such as DF (1979) and PP (1988) do not take into account structural breaks in the model, it has a lower power to reject the null hypothesis that indicates the existence of the unit root and is known to cause 
AEA

28,84 deviation (Perron, 1989). With respect to the unit root test process, Elliott et al. (1996) developed a test procedure based on the generalized least square (GLS) detrending to increase the power of the test process of Dickey and Fuller (1979). Moreover, KPSS and DFGLS are also linear unit root tests. The ADF, PP, KPSS and DF-GLS unit root test equations and their results, are summarized in Table 3.

From Table 3, it is evident that the null hypothesis of unit root is not rejected for all countries for ADF, PP and DF-GLS. However, the null hypothesis of unit root is rejected at the first difference for $\mathrm{ADF}$ and PP. These findings support that the unemployment hysteresis is valid for all countries. According to the KPSS test, the null hypothesis of unit root is not rejected for Bulgaria, Croatia, CzechR, Hungary, Kazakhstan and Slovenia. These findings highlight that the unemployment hysteresis is not valid for Bulgaria, Croatia, CzechR, Hungary, Kazakhstan and Slovenia.

\subsection{Second group: structural breaks unit root tests}

Zivot and Andrews (1992, ZA) suggested that the history of structural breaks should be intrinsic by criticizing Perron's (1989) external breakpoint hypothesis. The ZA test allows for one structural break and determines the time of structural breaks endogenously. Lumsdaine and Papell (1997) developed the ZA test, which considers two breaking structures, an endogenous one and/or two breaking unit root tests that were developed by Lee and Strazicich $(2003,2004)$. The breaks are generally included in the model using dummy variables. However, in this approach, the exact number and time of structural breaks should be known. This causes an unwanted pre-selection bias and weakens the test's strength (Enders and Lee, 2012; Maddala and Kim, 1998). However, these tests are criticized as the number of breaks and the structural forms should be known in advance.

Becker et al. (2006) suggested a new unit root test with a Fourier function and used a modified version of the KPSS framework to accommodate non-linear breaks under both the null and the alternative. This test is called the Fourier KPSS (FKPSS, 2006) test and captures smooth and sharp breaks. The power of the test is not affected by smooth or sharp breaks, structural break dates or the number of breaks. The ZA and FKPSS unit root test equations, and their results, are presented in Table 4.

According to the results of ZA, Model A is valid for Bulgaria, Croatia, CzechR, Estonia, KyrgyzR, Latvia, Lithuania, Poland, SlovakR, Slovenia, Model B for Hungary and Romania and Model $\mathrm{C}$ for Kazakhstan. In addition, the null hypotheses were rejected for Estonia, KyrgyzR, Latvia, Lithuania and the trend stationary with the structural break was found. The findings of the ZA test show that the unemployment hysteresis is valid for all countries except Estonia, KyrgyzR, Latvia and Lithuania. According to the consequences of the FKPSS, the null hypothesis of the unit root is not rejected for only CzechR and Estonia. These findings show that these series are stationary for only CzechR and Estonia.

\subsection{Third group: non-linear unit root tests}

Until the end of the 1970s, time series were modeled under the assumption of linearity. However, not all models are linear. Moreover, many real-world problems do not meet the assumptions of linearity. In addition, the reflection of social, political or economic changes is mostly reflected in non-linearity and smooth transition process, rather than revealing a sudden change. Non-linear unit root tests are successful in capturing non-linear patterns. In addition, non-linearity occurs in the form of structural changes in the deterministic components. That is, a broken time trend is a case of a non-linear time trend (Chen, 2014). In addition, failure to consider non-linearity will result in acceptance of the unit root null hypothesis. Non-linearity is included in the unit root process by Kapetanios et al. (2003). In 


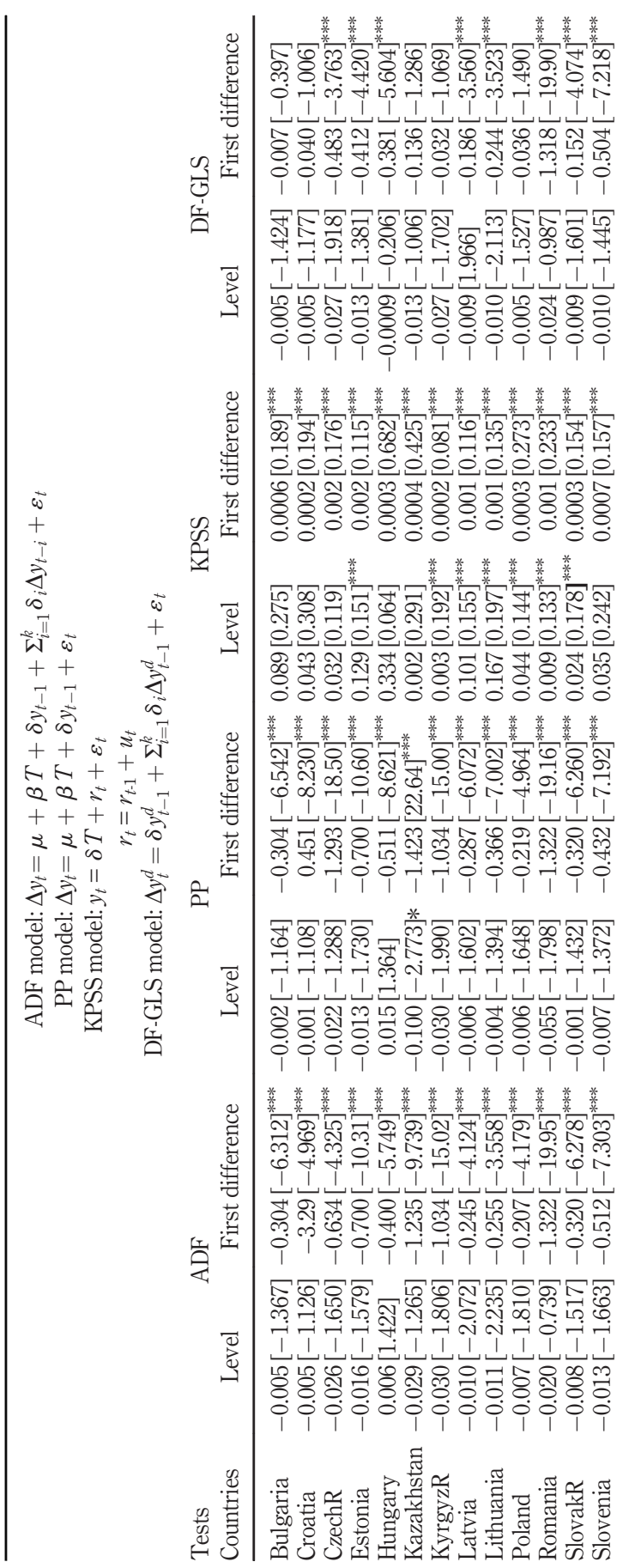

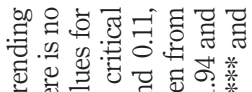

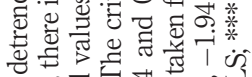

Q

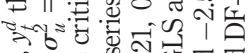

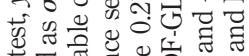

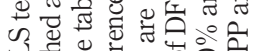

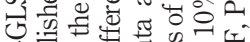

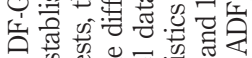

क्ष

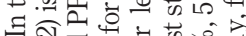

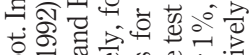

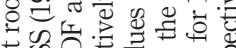

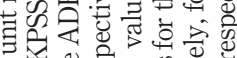
은 .

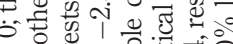

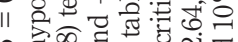
$\infty$ 在

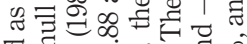
ช

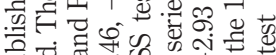

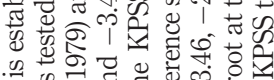
Transition economies

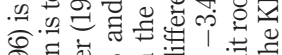

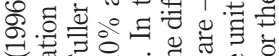

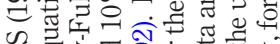

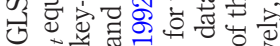

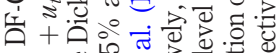

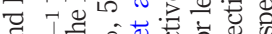

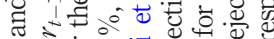
क 11

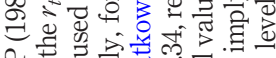

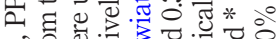

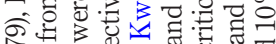
5े प्र 0

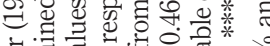

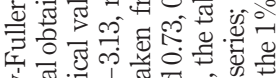

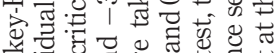
.

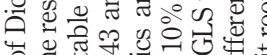

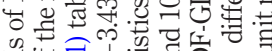
\%

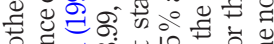
을 च

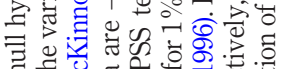
更 政

Table 3. Results of ADF, PP, is $\quad$ KPSS and DF-GLS unit root tests 
AEA

28,84

230
Table 4.

Results of ZA and FKPSS unit root tests

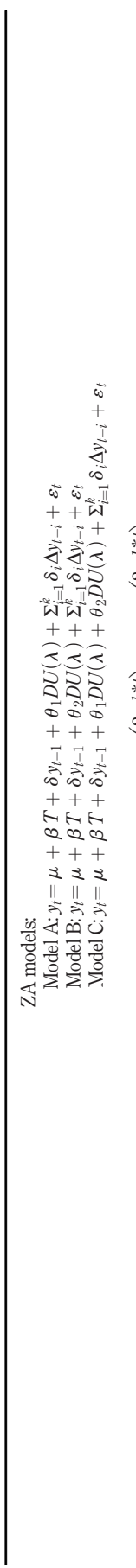

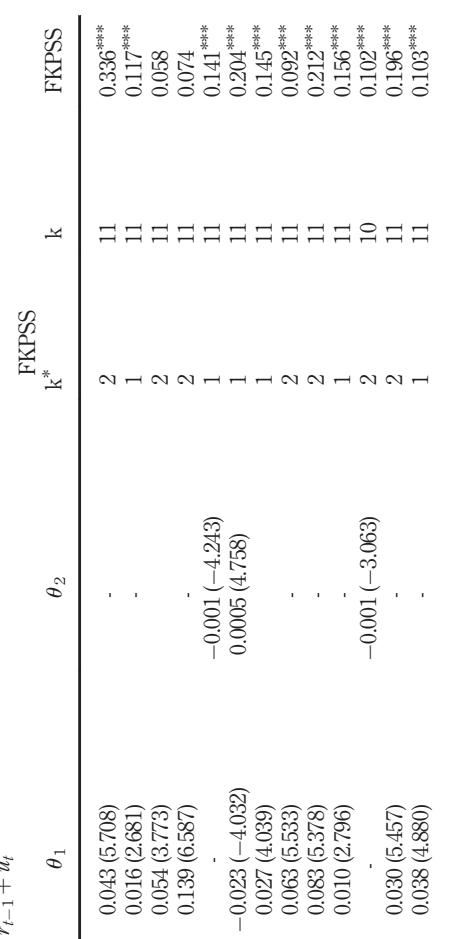

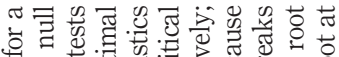

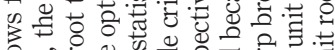

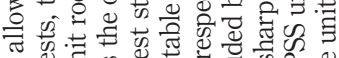
u国 on

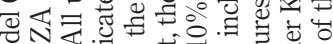

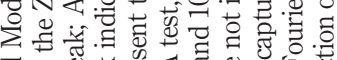

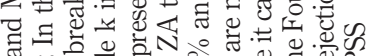

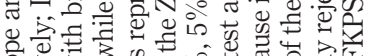

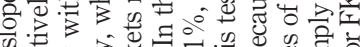

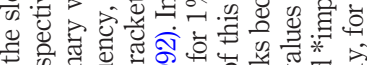
ヨ.

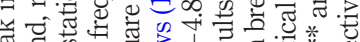

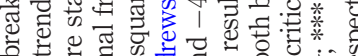

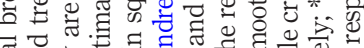

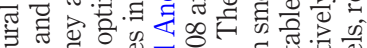

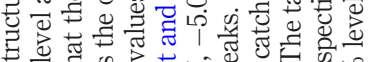

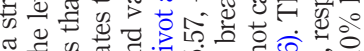

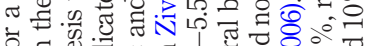

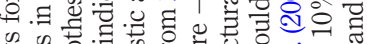

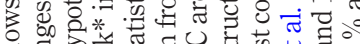

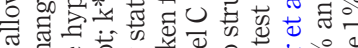

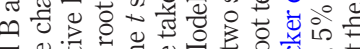
ब

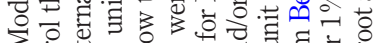

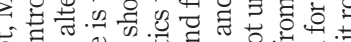

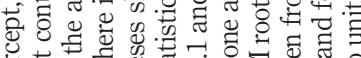

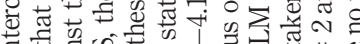
政语

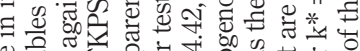

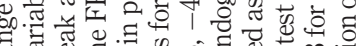

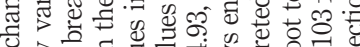

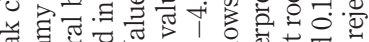

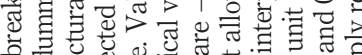

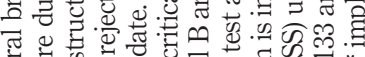

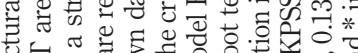
论

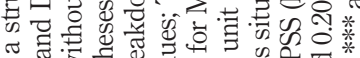

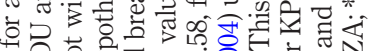
क

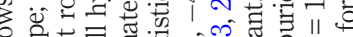

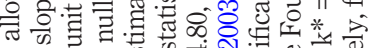

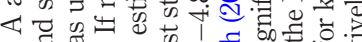
ब

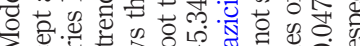

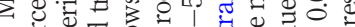

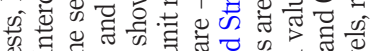

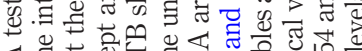

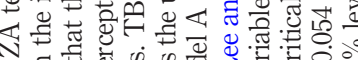

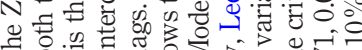

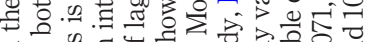

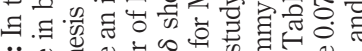

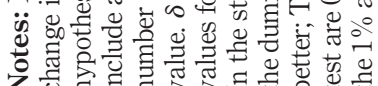


this test procedure, non-linearity is considered by using a smooth transition threshold autoregressive (STAR) model. This model type can be described as the exponential smooth transition threshold autoregressive (ESTAR) model. Sollis (2009) developed a unit root test based on the asymmetric exponential smooth transition threshold autoregressive model type, when Kruse (2011) developed a unit root test based on the ESTAR model type. The unit root test based on a logistic smooth transition threshold autoregressive model type was developed by Leybourne et al. (1998), Sollis (2004) and Pascalau (2007). Chong et al. (2008) and Cuestas and Garratt (2011) suggested non-linear unit root tests, which are specific tests, economies

and can be used to test economic hypotheses. In addition, Enders and Granger (1998) and Caner and Hansen (2001) tests are sharp transition non-linear unit root tests that reveal the presence of the unit root. These tests can be defined as compliant with a self-exciting threshold autoregressive model.

In this study, non-linear unit root tests based on the STAR model type are used. Transitions in the economic structure are often soft. For this reason, KSS (2003), Sollis (2009), CG (2011) and Kruse (2011) tests were used because of their higher test power. The non-linear unit root test equations, and their results, are presented in Table 5.

According to the non-linear unit root test results, the unit root hypothesis is not rejected for all countries. In the case of SlovakR for the KSS test, Romania for the Sollis test and Latvia, Romania and SlovakR for the Kruse test, hysteresis effects have not been observed

\begin{tabular}{|c|c|c|c|c|c|}
\hline Countries & $\mathrm{k}$ & $\begin{array}{l}\text { KSS model: } \Delta y_{t}= \\
\text { Sollis model: } \Delta y_{t}= \\
\text { CG Model 1: } y_{t}= \\
\text { CG Model 2: } \hat{\varepsilon}_{t}= \\
\text { Kruse model: } y_{t}= \\
\text { KSS }\end{array}$ & $\begin{array}{l}{ }_{i=1}^{k} \delta_{i} \Delta y_{t} \\
\theta_{2} y_{t-1}^{4} \\
+\alpha_{2} T^{2}+ \\
\theta_{2} \hat{\varepsilon}_{t-1}^{4} \\
\theta_{2} y_{t-1}^{2}+ \\
\text { Sollis }\end{array}$ & $\begin{array}{l}t_{t-i}+\varepsilon_{t} \\
{ }_{t}^{t} \hat{\varepsilon}_{t-i}+\varepsilon_{t} \\
-i+\varepsilon_{t} \\
\text { CG }\end{array}$ & Kruse \\
\hline Bulgaria & 6 & -2.294 & 2.704 & 3.586 & 7.047 \\
\hline Croatia & 6 & -2.064 & 2.617 & 1.468 & 7.112 \\
\hline CzechR & 5 & -2.085 & 2.807 & 3.529 & 6.963 \\
\hline Estonia & 8 & -2.643 & 3.634 & 4.577 & 7.184 \\
\hline Hungary & 8 & -1.033 & 0.628 & 6.914 & 2.639 \\
\hline Kazakhstan & 8 & -0.937 & 0.764 & 7.084 & 1.311 \\
\hline KyrgyzR & 1 & -0.637 & 0.359 & 0.419 & 0.717 \\
\hline Latvia & 7 & -3.159 & 5.197 & 6.949 & $11.16^{*}$ \\
\hline Lithuania & 6 & -2.280 & 3.100 & 3.667 & 8.022 \\
\hline Poland & 5 & -2.789 & 3.994 & 4.340 & 8.309 \\
\hline Romania & 3 & -0.966 & $7.161^{* *}$ & 8.203 & $13.49^{* *}$ \\
\hline SlovakR & 8 & $-3.304^{*}$ & 5.490 & 6.742 & $15.56^{* *}$ \\
\hline Slovenia & 7 & -1.903 & 2.012 & 3.284 & 6.578 \\
\hline
\end{tabular}

Notes: For the KSS test, if null hypotheses are $\theta=0$, there is unit root, while for Sollis, CG and for Kruse tests, if null hypotheses are $\theta_{1}=\theta_{2}=0$, there is unit root; Model 2 is estimated, as in the Sollis (2009) test, using residual from Model 1 in the Cuestas and Garratt test; $\mathrm{k}$ indicates the optimal number of lags. All unit root tests include intercepts and trends; Table critical values of unit root tests are taken from KSS (2003), Sollis (2009), Cuestas and Garratt (2011) and Kruse (2011). The critical values of the KSS unit root test are $-3.93,-3.40,-3.13$ and $1 \%, 5 \%$ and $10 \%$, respectively. Table critical values of the Sollis unit root test are 8.95, 6.59, 5.59; table critical values are 22.44, 17.27 and 14.97 for the CG unit root test, and 17.10, 12.82 and 11.10 for the Kruse unit root test for $1 \%, 5 \%$ and $10 \%$, respectively; $* *$ and *imply rejection of the unit root at the $5 \%$ and $10 \%$ levels, respectively

Table 5.

Results of non-linear unit root tests 
AEA 28,84

\section{2}

Table 6.

Results of Fourier Kruse unit root test because there was no unit root. According to the CG test result, there is a unit root for all countries, and the null hypothesis is not rejected.

\subsection{Fourth group: structural breaks and non-linear unit root tests}

The use of dummies in structural break unit root tests indicates sharp and sudden changes to the slope or constant. However, these tests will not provide sensitive results if the breaks are smooth. Moreover, it was emphasized by Leybourne et al. (1998) that breaks should be considered as smooth and progressive processes. Thus, because the reflection of structural breaks takes a certain time, this makes the transition smooth. Becker et al. (2006) developed a unit root test with a Fourier function to catch smooth breaks. The behavior of a nonperiodic and unknown function can be captured using the Fourier function. When we consider the tests that accommodate structural breaks and non-linearity, the Fourier KSS test developed by Christopoulos and Leon-Ledesma (2010) and Fourier Kruse unit root tests developed by Guris (2019) are the most effective. In this study, the hysteresis effect was investigated using the Fourier Kruse (Guris, 2019) test because it has higher test power. The Fourier Kruse unit root test equations, and their results, are listed in Table 6.

For all countries except Kazakhstan and SlovakR, the null hypothesis could not be rejected, and it was found that the series contained unit roots. In the case of the Kazakhstan and the SlovakR, the $F$ test proposed by Becker et al. (2006) was applied, and it was concluded that the series was stationary around the broken deterministic function. According to these findings, the unemployment hysteresis hypothesis holds true in all cases except the Kazakhstan and the SlovakR.

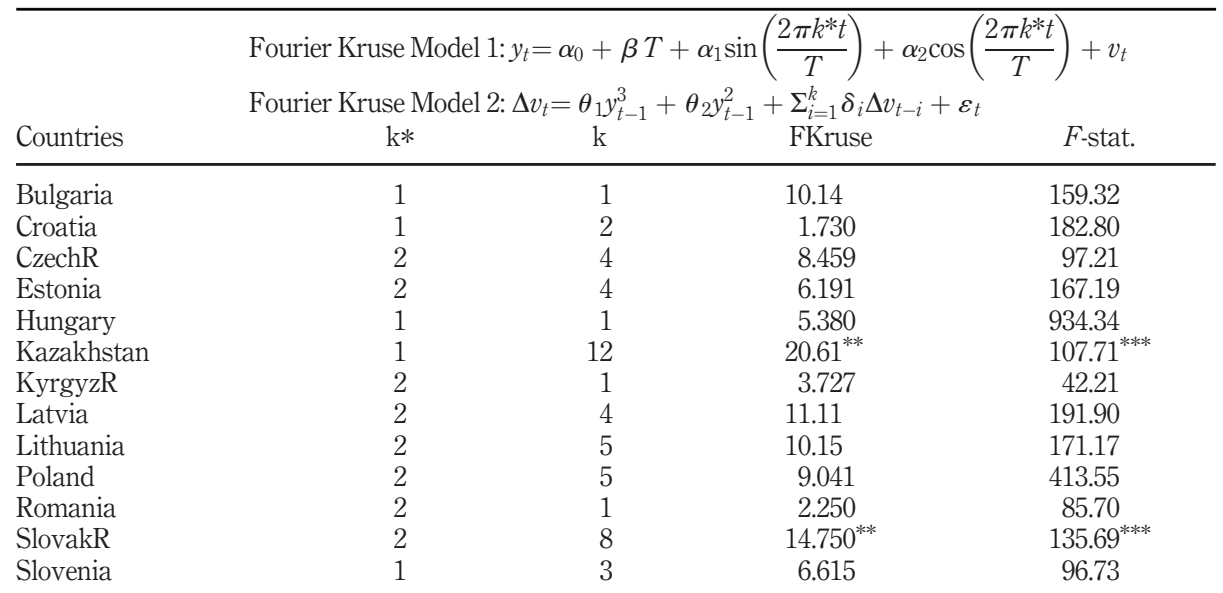

Notes: All unit root tests include an intercept and trend; If null hypotheses are $\theta_{1}=\theta_{2}=0$, there is unit root; Model 2 is estimated, as in Kruse (2011) test, using error terms from Model 1; $\mathrm{k}^{*}$ indicates the optimal frequency, while $\mathrm{k}$ indicates the optimal number of lags; Table critical values of unit root tests are taken from Guris (2019). The table critical values of the FKruse unit root test are 23.56, 18.54, 15.74 for $\mathrm{k}^{*}=1$ and 18.78, 14.2, 12.32 for $\mathrm{k}^{*}=2$ and Becker et al. (2006) $F$ table value is $6.87,4.97$ and 3.92 for $1 \%, 5 \%$ and $10 \%$, respectively; In case, the unit root null hypothesis is rejected, Becker et al. (2006) used the $F$ statistic to test the null hypothesis of the absence of the non-linear trend suggested in the study, and the rejection of the null hypothesis states that the series is stationary around the broken deterministic function; *** and ** imply rejection of the unit root at the $1 \%$ and $5 \%$ levels, respectively 


\subsection{Comparison of the unit root tests}

The results regarding the existence of unit root tests are mixed for a few countries. It is very important to lay out the structure of the data and to perform the appropriate test accordingly. Thus, we compared the results of the unit root tests implemented in this study, and a comparison of these tests is displayed in Table 7.

According to ADF, PP and DF-GLS unit root tests, the unemployment hysteresis is valid for all selected countries. According to the KPSS test, the null hypothesis of unit root is not rejected for Bulgaria, Croatia, CzechR, Hungary, Kazakhstan and Slovenia. The ZA unit root economies test results show that the null hypotheses were rejected for Estonia, KyrgyzR, Latvia, Lithuania and the trend stationary with the structural break was found. According to the consequences of the FKPSS, the series is stationary for only CzechR and Estonia. When we look at the non-linear tests, it is seen that the results exhibit differences. Additionally, the unit root hypothesis could not be rejected for all countries. According to the KSS, the unemployment hysteresis is not valid for the SlovakR. There was no hysteresis effect for Romania using the Sollis test, nor Latvia, Romania and SlovakR, for the Kruse test. According to the CG test result, there is unit root for all countries and the null hypothesis could not be rejected. The FKruse test results revealed that the unemployment hysteresis is valid for all countries except Kazakhstan and SlovakR.

Generally, the findings of the study show that the unemployment hysteresis is valid in 11 out of the 13 transition economies. It is invalid for the Kazakhstan and SlovakR, attributable to the following factors: Kazakhstan is characterized by comparatively high labor market performance, as high labor force participation rates, low inactivity and low unemployment were observed even during the economic recession. Long-term unemployment remains very low (Strokova et al., 2016). Another particularity of Kazakhstan's labor market is its widely used vocational guidance, vocational training and retraining programs (ILO, 2015).

In the SlovakR, the employers' right to fire workers was considerably more restricted (Domonkos, 2016), together with its measures focused on job creation and the retraining of jobseekers (Ham et al., 1995). The share of spending on these programs exceeded $80 \%$ of the total spend on active labor market policies (Terrell et al., 1996).

Our findings contradict those of León-Ledesma and Mcadam (2004). They rejected the unit root hypothesis after controlling for structural changes and business cycle effects in the case of CEE countries. Similar findings have been obtained by Bechný (2019) and Furuoka

\begin{tabular}{|c|c|c|c|c|c|c|c|c|c|c|c|}
\hline Countries & $\mathrm{ADF}$ & $\mathrm{PP}$ & KPSS & DFGLS & $\mathrm{ZA}$ & FKPSS & KSS & Sollis & CG & Kruse & FKruse \\
\hline Bulgaria & & & $\mathrm{X}$ & & & $\sqrt{ }$ & $\sqrt{ }$ & $\sqrt{ }$ & & & $\sqrt{ }$ \\
\hline Croatia & & & $\mathrm{X}$ & & & $\sqrt{ }$ & & $\sqrt{ }$ & & $v$ & $\sqrt{ }$ \\
\hline CzechR & $\sqrt{ }$ & $\sqrt{ }$ & $\mathrm{X}$ & $\sqrt{ }$ & & $\mathrm{X}$ & $\sqrt{ }$ & $\sqrt{ }$ & & $\sqrt{ }$ & $\sqrt{ }$ \\
\hline Estonia & $\sqrt{ }$ & $\sqrt{ }$ & & $\mathrm{X}$ & & $\mathrm{X}$ & $\sqrt{ }$ & $\sqrt{ }$ & & $\sqrt{ }$ & $\sqrt{ }$ \\
\hline Hungary & $\sqrt{ }$ & $\sqrt{ }$ & $\mathrm{X}$ & $\sqrt{ }$ & & $\sqrt{ }$ & $\sqrt{ }$ & $\sqrt{ }$ & & $\sqrt{ }$ & $\sqrt{ }$ \\
\hline Kazakhstan & $\sqrt{ }$ & $\sqrt{ }$ & $\mathrm{X}$ & $\sqrt{ }$ & & $\sqrt{ }$ & $\sqrt{ }$ & $\sqrt{ }$ & & $\sqrt{ }$ & $\mathrm{X}$ \\
\hline KyrgyzR & $\sqrt{ }$ & $\sqrt{ }$ & $\sqrt{ }$ & $\mathrm{X}$ & & $\sqrt{ }$ & $\sqrt{ }$ & $\sqrt{ }$ & & $\sqrt{ }$ & $\sqrt{ }$ \\
\hline Latvia & $\sqrt{ }$ & $\sqrt{ }$ & $\sqrt{ }$ & $\mathrm{X}$ & & $\sqrt{ }$ & $\sqrt{ }$ & $\sqrt{ }$ & & X & $\sqrt{ }$ \\
\hline Lithuania & $\sqrt{ }$ & & $\sqrt{ }$ & $\mathrm{X}$ & & $\sqrt{ }$ & $\sqrt{ }$ & $\sqrt{ }$ & & $\sqrt{ }$ & $\sqrt{ }$ \\
\hline Poland & $\sqrt{ }$ & $\sqrt{ }$ & $\sqrt{ }$ & $\sqrt{ }$ & & $\sqrt{ }$ & $\sqrt{ }$ & $\sqrt{ }$ & $\sqrt{2}$ & $\sqrt{ }$ & $\sqrt{ }$ \\
\hline Romania & $\sqrt{ }$ & $\sqrt{ }$ & $\sqrt{ }$ & $\sqrt{ }$ & & $\sqrt{ }$ & $\sqrt{ }$ & $\dot{X}$ & V & X & $\sqrt{ }$ \\
\hline SlovakR & $\sqrt{ }$ & $\sqrt{ }$ & $\sqrt{ }$ & $\sqrt{ }$ & & $\sqrt{ }$ & X & $\sqrt{ }$ & 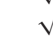 & X & X \\
\hline Slovenia & & $\sqrt{ }$ & $\dot{X}$ & $\sqrt{ }$ & & $\sqrt{ }$ & $\sqrt{ }$ & $\sqrt{ }$ & & $\sqrt{ }$ & $\sqrt{ }$ \\
\hline
\end{tabular}

Note: $\sqrt{ }$ implies that there is unit root 
AEA 28,84

(2014) for CzechR. In addition, our findings concur with Gozgor (2013) results in the case of 10 CEE countries.

\section{Conclusion}

In this study, alternative approaches to unemployment hysteresis have been tested for selected transition economies by using different unit root tests that focus on the different properties of the time series. It was revealed that the results were highly dependent on the power of the unit root tests applied. Moreover, if non-linearity and/or structural breaks are not taken into consideration, the series may present as if it is not stationary.

When unit root tests are applied to unemployment rates, we find mixed evidence for hysteresis for all countries. The results of the study show that the unemployment hysteresis is valid in 11 out of the 13 countries in transition (Bulgaria, Croatia, CzechR, Estonia, Hungary, KyrgyzR, Latvia, Lithuania, Poland, Romania and Slovenia), while the unemployment hysteresis is not valid for the Kazakhstan and SlovakR. According to our findings, the unemployment rate of most transition economies is permanently affected by shocks. The deviation that will occur in the average unemployment rate affects the macro economy. Therefore, a rather structural approach is needed to reduce the unemployment rate. As a result of crisis, breaks and shocks in the economy, the unemployment rate series will not return to its previous level and will tend to remain at the new balance level. Negative effects caused by these structural changes need to be reduced, thus structural reforms are needed to increase the efficiency of transition economies in the labor market.

\section{References}

Akdogan, K. (2017), "Unemployment hysteresis and structural change in Europe", Empirical Economics, Vol. 53 No. 4, pp. 1415-1440.

Albulescu, C.T. and Tiwari, A.K. (2018), "Unemployment persistence in EU countries: new evidence using bounded unit root tests", Applied Economics Letters, Vol. 25 No. 12, pp. 807-810.

Arestis, P. and Mariscal, I.B.F. (2000), "OECD unemployment: structural breaks and stationarity", Applied Economics, Vol. 32 No. 4, pp. 399-403.

Bahmani-Oskooee, M., Chang, T. and Ranjbar, O. (2018), "Testing hysteresis effect in U.S. state unemployment: new evidence using a nonlinear quantile unit root test", Applied Economics Letters, Vol. 25 No. 4, pp. 249-253.

Becker, R., Enders, W. and Lee, J. (2006), "A stationarity test in the presence of an unknown number of smooth breaks", Journal of Time Series Analysis, Vol. 27 No. 3, pp. 381-409.

Bechný, J. (2019), "Unemployment hysteresis in the Czech Republic", Prague Economic Papers, Vol. 28 No. 5, pp. 532-546.

Bisaglia, L. and Gerolimetto, M. (2014), "Testing for (non)linearity in economic time series: a Monte Carlo comparison”, working paper series, No. 3, University of Padua, Department of Statistical Sciences.

Blanchard, O.I. and Summers, L.H. (1986), "Hysteresis and the European unemployment problem", in Fischer, F. (Ed.), Macroeconomics Annual, MIT Press, Cambridge.

Blanchard, O.I. and Summers, L.H. (1987), "Hysteresis in unemployment", European Economic Review, Vol. 31 Nos 1/2, pp. 288-295.

Boeri, T. and Terrell, K. (2002), "Institutional determinants of labor reallocation in transition", Journal of Economic Perspectives, Vol. 16 No. 1, pp. 51-76.

Bolat, S., Tiwari, K.A. and Erdayi, A.U. (2014), "Unemployment hysteresis in the Eurozone area: evidences from nonlinear heterogeneous panel unit root test", Applied Economics Letters, Vol. 21 No. 8, pp. 536-540. 
Brunello, G. (1990), "Hysteresis and the Japanese unemployment problem: a preliminary investigation", Oxford Economic Papers, Vol. 42 No. 3, pp. 483-500.

Camarero, M. and Tamarit, C. (2004), "Hysteresis vs. natural rate of unemployment: new evidence for OECD countries", Economics Letters, Vol. 84 No. 3, pp. 413-417.

Camarero, M., Carrion-I-Silvestre, J.L. and Tamarit, C. (2005), "Unemployment dynamics and NAIRU estimates for accession countries: a univariate approach", Journal of Comparative Economics, Vol. 33 No. 3, pp. 584-603.

Camarero, M., Carrión-I-Silvestre, J.L. and Tamarit, C. (2008), "Unemployment hysteresis in transition countries: evidence using stationarity panel tests with breaks", Review of Development Economics, Vol. 12 No. 3, pp. 620-635.

Caner, M. and Hansen, B.E. (2001), "Threshold autoregression with a unit root”, Econometrica, Vol. 69 No. 6, pp. 1555-1596.

Carlin, W. and Soskice, D. (1990), Macroeconomics and the Wage Bargain: A Modern Approach to Employment Inflation and the Exchange Rate, Oxford University Press, Oxford.

Cavaliere, G. and Xu, F. (2014), "Testing for unit roots in bounded time series", Journal of Econometrics, Vol. 178, pp. 259-272.

Cazes, S. (2002), "Do labor market institutions matter in transition economies? An analysis of labor market flexibility in the late nineties", Discussion paper 140/2002, International Institute for Labor Studies, ILO.

Chang, T. (2011), "Hysteresis in unemployment for 17 OECD countries: stationary test with a fourier function”, Economic Modelling, Vol. 28 No. 5, pp. 2208-2214.

Chang, T. and Lee, C.H. (2011), "Hysteresis in unemployment for G-7 countries: threshold unit root test", Romanian Journal of Economic Forecasting, Vol. 14 No. 4, pp. 5-14.

Chen, S.W. (2014), "Smooth transition, non-linearity and current account sustainability: evidence from the European countries", Economic Modelling, Vol. 38, pp. 541-554.

Cheng, K.M., Durmaz, N., Kim, H. and Stern, M.L. (2012), "Hysteresis vs natural rate of US unemployment", Economic Modelling, Vol. 29 No. 2, pp. 428-434.

Cheng, S.C., Wu, T., Lee, K.C. and Chang, T. (2014), "Flexible fourier unit root test of unemployment for PIIGS countries", Economic Modelling, Vol. 36, pp. 142-148.

Chong, T.T.L., Hinich, M.J., Liew, V.K.S. and Lim, K.P. (2008), "Time series test of nonlinear convergence and transitional dynamics", Economics Letters, Vol. 100 No. 3, pp. 337-339.

Christopoulos, D.K. and Leon-Ledesma, M.A. (2010), "Smooth breaks and non-linear mean reversion: post-Bretton woods real exchange rates", Journal of International Money and Finance, Vol. 29 No. 6, pp. 1076-1093.

Cuestas, J.C. and Garratt, D. (2011), "Is real GDP per capita a stationary process? Smooth transitions, nonlinear trends and unit root testing", Empirical Economics, Vol. 41 No. 3, pp. 555-563.

Dickey, D.A. and Fuller, W.A. (1979), "Distribution of the estimators for autoregressive time series with a unit root", Journal of the American Statistical Association, Vol. 74 No. 366, pp. 427-431.

Domonkos, S. (2016), "Economic transition, partisan politics and EU austerity: a case study of Slovakia's labor market policies”, working paper 2016.04, European Trade Union Institute.

Elliott, G., Rothenberg, T.J. and Stock, J.H. (1996), "Efficient tests for an autoregressive unit root", Econometrica, Vol. 64 No. 4, pp. 813-836.

Enders, W. and Granger, C.W.J. (1998), "Unit-root tests and asymmetric adjustment with an example using the term structure of interest rates", Journal of Business and Economic Statistics, Vol. 16 No. 3, pp. 304-311.

Enders, W. and Lee, J. (2012), "A unit root test using a fourier series to approximate smooth breaks", Oxford Bulletin of Economics and Statistics, Vol. 74 No. 4, pp. 574-599. 
AEA 28,84

Feve, P., Henin, P.Y. and Jolivaldt, P. (2003), “Testing for hysteresis: unemployment persistence and wage adjustment", Empirical Economics, Vol. 28 No. 3, pp. 535-552.

Furuoka, F. (2014), "Does hysteresis exist in unemployment? New findings from fourteen regions of the Czech Republic", Czech Journal of Economics and Finance, Vol. 64 No. 1, pp. 59-78.

Furuoka, F. (2017a), "A new test for analyzing hysteresis in European unemployment", Applied Economics Letters, Vol. 24 No. 15, pp. 1102-1106.

Furuoka, F. (2017b), "A new approach to testing unemployment hysteresis”, Empirical Economics, Vol. 53 No. 3, pp. 1253-1280.

Garcia-Cintado, A., Romero-Ávila, D. and Usabiaga, C. (2015), "Can the hysteresis hypothesis in Spanish regional unemployment be beaten? New evidence from unit root tests with breaks", Economic Modelling, Vol. 47, pp. 244-252.

Gomes, F. and da Silva, C.G. (2008), "Hysteresis vs. natural rate of unemployment in Brazil and Chile", Applied Economics Letters, Vol. 15 No. 1, pp. 53-56.

Gozgor, G. (2013), "Testing unemployment persistence in Central and Eastern European countries", International Journal of Economics and Financial Issues, Vol. 3 No. 3, pp. 694-700.

Guris, B. (2019), "A new nonlinear unit root test with fourier function”, Communications in StatisticsSimulation and Computation, Vol. 48 No. 10, pp. 3056-3062.

Guris, B., Tiftikcigil, B.Y. and Tirasoglu, M. (2017), "Testing for unemployment hysteresis in Turkey: evidence from nonlinear unit root tests", Quality Quantity, Vol. 51 No. 1, pp. 35-46.

Gustavsson, M. and Österholm, P. (2006), "Hysteresis and nonlinearities in unemployment rates", Applied Economics Letters, Vol. 13 No. 9, pp. 545-548.

Ham, J., Svejnar, J. and Terrell, K. (1995), “Czech Republic and Slovakia”, in Commander, S. and Coricelli F. (Eds), Unemployment, Restructuring and the Labor Market in Eastern Europe and Russia, World Bank, Washington, DC, pp. 91-146.

Harvey, D.I. and Leybourne, S.J. (2007), "Testing for time series linearity”, The Econometrics Journal, Vol. 10 No. 1, pp. 149-165.

Harvey, D.I., Leybourne, S.J. and Xiao, B. (2008), "A powerful test for linearity when the order of integration is unknown", Studies in Nonlinear Dynamics and Econometrics, Vol. 12 No. 3, pp. 1-24.

International Financial Statistics (IFS) (2019), available at: www.imf.org (accessed 21 December 2019).

ILO (2015), Jobs and Skills for Youth: review of Policies for Youth Employment of Kazakhstan, International Labour Office, Geneva.

Kapetanios, G., Shin, Y. and Snell, A. (2003), "Testing for a unit root in the nonlinear STAR framework", Journal of Econometrics, Vol. 112 No. 2, pp. 359-379.

Keenan, D.M. (1985), “A tukey non-additivity-type test for time series nonlinearity”, Biometrika, Vol. 72 No. 1, pp. 39-44.

Khraief, N., Shahbaz, M., Heshmati, A. and Azam, M. (2020), "Are unemployment rates in OECD countries stationary? Evidence from univariate and panel unit root tests", The North American Journal of Economics and Finance, Vol. 51.

Kruse, R. (2011), "A new unit root test against ESTAR based on a class of modified statistics", Statistical Papers, Vol. 52 No. 1, pp. 71-85.

Kwiatkowski, D., Phillips, P.C., Schmidt, P. and Shin, Y. (1992), "Testing the null hypothesis of stationarity against the alternative of a unit root”, Journal of Econometrics, Vol. 54 Nos 1/3, pp. 159-178.

Lee, J. and Strazicich, M.C. (2003), "Minimum lagrange multiplier unit root test with two structural breaks", Review of Economics and Statistics, Vol. 85 No. 4, pp. 1082-1089.

Lee, J. and Strazicich, M.C. (2004), "Minimum LM unit root test with one structural break", working paper 04-17, Appalachian State University. 
Lee, J.D., Lee, C.C. and Chang, C.P. (2009), "Hysteresis in unemployment revisited: evidence from panel LM unit root tests with heterogeneous structural breaks", Bulletin of Economic Research, Vol. 61 No. 4, pp. 325-334.

Lee, H.Y., Wu, J.L. and Lin, C.H. (2010), "Hysteresis in East Asian unemployment”, Applied Economics, Vol. 42 No. 7, pp. 887-898.

León-Ledesma, M.A. and McAdam, P. (2004), "Unemployment, hysteresis and transition”, Scottish Journal of Political Economy, Vol. 51 No. 3, pp. 377-401.

Leybourne, S., Newbold, P. and Vougas, D. (1998), "Unit roots and smooth transitions”, Journal of Time Series Analysis, Vol. 19 No. 1, pp. 83-97.

Lin, C.H., Kuo, N.F. and Yuan, C.D. (2008), "Nonlinear vs. nonstationary of hysteresis in unemployment: evidence from OECD economies", Applied Economics Letters, Vol. 15 No. 6, pp. 483-487.

Ljung, G.M. and Box, G.E. (1978), "On a measure of lack of fit in time series models", Biometrika, Vol. 65 No. 2, pp. 297-303.

Lumsdaine, R.L. and Papell, D.H. (1997), "Multiple trend breaks and the unit-root hypothesis", Review of Economics and Statistics, Vol. 79 No. 2, pp. 212-218.

McLeod, A.I. and Li, W.K. (1983), "Diagnostic checking ARMA time series models using squared residual autocorrelations", Journal of Time Series Analysis, Vol. 4 No. 4, pp. 269-273.

MacKinnon, J.G. (1991), “Critical values for cointegration tests”, in Engle R.F. and Granger, C.W.J. (Eds), Long-Run Economic Relationships: Readings in Cointegration, Oxford University Press, Oxford, pp. 267-276.

Maddala, G. and Kim, I.M. (1998), Unit Roots, Cointegration and Structural Change, Cambridge University Press, Cambridge.

Meng, M., Strazicich, M.C. and Lee, J. (2017), "Hysteresis in unemployment? Evidence from linear and nonlinear unit root tests and tests with non-normal errors", Empirical Economics, Vol. 53 No. 4, pp. 1399-1414.

Nesporova, A. (1999), Employment and Labour Market Policies in Transition Economies, International Labour Office, Geneva.

Nesporova, A. (2002), "Unemployment in the transition economies", paper presented at the UNECE conference, Geneva, 5-7 May.

Pascalau, R. (2007), "Testing for a unit root in the asymmetric nonlinear smooth transition framework", unpublished manuscript, Department of Economics, Finance and Legal Studies, University of Alabama.

Petreski, M. (2020), "Winners or losers? Workers in transition economies under globalization", PostCommunist Economies, Vol. 32 No. 4, pp. 468-494.

Perron, P. (1989), "The great crash, the oil price shock and the unit root hypothesis", Econometrica, Vol. 57 No. 6, pp. 1361-1401.

Phillips, P.C.B. and Perron, P. (1988), "Testing for unit roots in time series regression”, Biometrika, Vol. 75 No. 2, pp. 335-346.

Røed, K. (1996), "Unemployment hysteresis - macro evidence from 16 OECD countries", Empirical Economics, Vol. 21, pp. 589-600.

Romero-Ávila, D. and Usabiaga, C. (2007), "Unit root tests and persistence of unemployment: Spain vs the United States”, Applied Economics Letters, Vol. 14 No. 6, pp. 457-461.

Smyth, R. (2003), "Unemployment hysteresis in Australian states and territories: evidence from panel data unit root tests", The Australian Economic Review, Vol. 36 No. 2, pp. 181-192.

Sollis, R. (2004), "Asymmetric adjustment and smooth transitions: a combination of some unit root tests", Journal of Time Series Analysis, Vol. 25 No. 3, pp. 409-417.

Sollis, R. (2009), "A simple unit root test against asymmetric STAR nonlinearity with an application to real exchange rates in Nordic countries", Economic Modelling, Vol. 26 No. 1, pp. 118-125. 
AEA

28,84

Strokova, V., Elzir, A. and Margolis, D. (2016), Labor Market Outcomes Kazakhstan, World Bank Group Washington, D.C.

Svejnar, J. (1999), "Labor markets in the transitional Central and Eastern European economies", in Ashenfelter, O. and Card, D. (Eds) Handbook of Labor Economics, New York, NY and Oxford, Elsevier Science, North-Holland, pp. 2809-2857.

Terrell, K. and Jurajda, S. (2007), "Regional unemployment and human capital in transition economies", IZA Discussion Paper No. 3176.

Terrell, K., Lubyová, M. and Strapec, M. (1996), "Evidence on the implementation and effectiveness of passive and active labor market policies in the Slovak Republic", Lessons from Labor Market Policies in the Transition Countries, Organization for Economic Cooperation and Development, Paris, pp.227-265.

Tsay, R.S. (1986), "Nonlinearity tests for time series", Biometrika, Vol. 73 No. 2, pp. 461-466.

Ucar, N. and Omay, T. (2009), "Testing for unit root in nonlinear heterogeneous panels", Economics Letters, Vol. 104 No. 1, pp. 5-8.

Yaya, O.S., Ogbonna, A.E. and Mudida, R. (2019), "Hysteresis of unemployment rates in Africa: new findings from fourier ADF test”, Quality and Quantity, Vol. 53 No. 6, pp. 2781-2795.

Zivot, E. and Andrews, D. (1992), "Further evidence on the great crash, the oil price shock, and the unit root hypothesis", Journal of Business and Economic Statistics, Vol. 10 No. 3, pp. 251-270.

\section{Corresponding author}

Zamira Oskonbaeva can be contacted at: zamira.oskonbaeva@manas.edu.kg

For instructions on how to order reprints of this article, please visit our website: www.emeraldgrouppublishing.com/licensing/reprints.htm Or contact us for further details: permissions@emeraldinsight.com 